\title{
Editorial: Habitat Modification and Landscape Fragmentation in Agricultural Ecosystems: Implications for Biodiversity and Landscape Multi-Functionality
}

\author{
Georg K. S. Andersson ${ }^{1 *}$, Elena D. Concepción ${ }^{2,3}$, Juliana Hipólito ${ }^{4,5}$, Manuel B. Morales ${ }^{6}$ \\ and Anna S. Persson ${ }^{7}$ \\ ${ }^{1}$ Department of Biology, Lund University, Lund, Sweden, ${ }^{2}$ Department of Biogeography and Global Change, National \\ Museum of Natural Sciences (BGC-MNCN-CSIC), Madrid, Spain, ${ }^{3}$ Biodiversity, Ecology and Evolution Department, Faculty \\ of Biological Sciences, Complutense University of Madrid, Madrid, Spain, ${ }^{4}$ Biology Institute, Federal University of Bahia, \\ Salvador, Brazil, ${ }^{5}$ National Institute for Research in the Amazon (INPA), Manaus, Brazil, ${ }^{6}$ Department of Ecology and \\ Research Center for Biodiversity and Global Change (CIBC_UAM), Universidad Autónoma de Madrid, Madrid, Spain, \\ ${ }^{7}$ Centre for Environmental and Climate Science (CEC), Lund University, Lund, Sweden
}

Keywords: biodiversity, ecosystem function, habitat loss, fragmentation, agro-ecosystem, ecosystem service, multi-functionality

\section{OPEN ACCESS}

Edited and reviewed by:

Daniel de Paiva Silva,

Goiano Federal Institute (IFGOIANO), Brazil

*Correspondence:

Georg K. S. Andersson georg.andersson@cec.lu.se

Specialty section:

This article was submitted to Biogeography and Macroecology,

a section of the journal

Frontiers in Ecology and Evolution

Received: 21 October 2021 Accepted: 04 November 2021 Published: 01 December 2021

Citation

Andersson GKS, Concepción ED,

Hipólito J, Morales MB and Persson AS (2021) Editorial: Habitat Modification and Landscape Fragmentation in Agricultural Ecosystems: Implications for Biodiversity and Landscape

Multi-Functionality.

Front. Ecol. Evol. 9:799322. doi: 10.3389/fevo.2021.799322
Editorial on the Research Topic

Habitat Modification and Landscape Fragmentation in Agricultural Ecosystems: Implications for Biodiversity and Landscape Multi-Functionality

\section{INFLUENCE OF HABITAT LOSS AND FRAGMENTATION IN AGRICULTURAL ECOSYSTEMS}

Biodiversity is the basis of several important ecosystem functions, which guarantee the provision of irreplaceable Nature's contribution to people, for example food production. Long-term maintenance of such functions and services in agricultural ecosystems thus depend on the maintenance of the biodiversity of agro-ecosystems (Foley et al., 2005; Tomlinson, 2013). Biodiversity loss is therefore a major global environmental problem, with habitat deterioration being one of the main drivers (Tilman, 2001; Brook et al., 2008). As habitat loss is one consequence of agricultural intensification (Benton et al., 2003), and agricultural ecosystems comprise $40 \%$ of Earth's land ecosystems (FAO, 2021), agriculture plays a critical role for biodiversity and ecosystem functioning at large.

However, the influence of habitat loss, fragmentation and modifications in agricultural ecosystems on biodiversity and ecosystem functions is still hard to disentangle from that of other mechanisms. For some taxa or ecosystem services (e.g., pollinators and pollination), landscape and habitat modification have been shown to be important, e.g., as increasing habitat fragmentation or crop isolation from natural areas decrease pollination services (Ricketts et al., 2008; Farwig et al., 2009; Garibaldi et al., 2009, 2011). For other groups or services (e.g., seed dispersal and predation) this has so far not been thoroughly investigated (but see Perrot et al.). Landscape and habitat changes can have different effects on biodiversity and ecosystem services depending on not only the taxon or function investigated, but also on landscape structure (Viana et al., 2012), 
local management (Holzschuh et al., 2008; Vergara and Badano, 2009; Batáry et al., 2012; Kennedy et al., 2013; Rundlöf et al., 2015; Hipólito et al., 2018) or the interaction between these factors (Concepción et al., 2012; Andersson et al., 2014; Faria and Morales, 2021; Tarjuelo et al., 2021).

This issue compiles studies from three continents on different aspects of fragmentation and habitat modification in agricultural ecosystems. Studies include a broad range of organisms: plants, arthropods, birds and bats, as well as multiple functions. We were able to bring together authors and reviewers from different countries around the world (Brazil, Chile, Argentina, Spain, Portugal, France, Sweden and Australia) to share some fresh and innovative approaches evidencing the critical role of biodiversity in the functioning of agricultural ecosystems and how this is modulated by landscape structure and human landuse across spatial and temporal scales. Under this conceptual framework, the reader of this special issue will learn about the significant value for ant conservation of even small and isolated habitat patches, which play several important ecological roles in agroecosystems (Azcárate et al.). This study highlights the need to rethink how small natural habitats inserted in an agricultural matrix can be protected and managed, and how the complex interactions between organisms and landscape factors result in the need to include multiple spatial scales in management and conservation planning. The effect of some management strategies may be particularly complex and depend on both the spatial scale and taxon investigated. For example, Nilsson et al. show that annual flower strips favored the abundance of hoverfly larvae and possibly solitary bees, but had no significant effects on either natural enemies or natural pest control. In the wider landscape, however, the abundance of bees was not affected by annual flower strips (but see Jönsson et al., 2015) and the authors conclude that permanent non-crop structures are likely more important for many organisms.

On one hand, results published in this special issue support the idea that both landscape heterogeneity and configuration contribute to explain the three properties of functional diversity, as shown for bees in Coutinho et al. However, differences can be found between taxonomic groups. For example, bird species richness and abundance did not show a significant response to the amount of neighboring native grassland in restored Brazilian grasslands (da Silva and Fontana), although small landscape elements can double the landscape connectivity compared to a theoretical baseline landscape containing no such elements, with riparian forests contributing the most to enhance landscape connectivity (Siqueira et al.). Although logged forests tend to recover their height after a decade, they do not recover the original forest cover, measured by the Normalized Difference Vegetation Index. Likewise, decade-long recovering stands continue to show lower avian species richness and abundance, and different community composition than unlogged forests (Ribeiro et al.).

Understanding and addressing the effect of spatial scales on agro-ecosystem structure and functioning are critical for conserving farmland biodiversity (Ekroos et al., 2016). Therefore, this is another topic central to this special issue. For example, resolution of the geographical data (land cover) used will affect the relationship found between landscape complexity and species richness and abundance. In this line of evidence, Carneiro et al., report a strong and positive influence of landscape heterogeneity in low thematic resolution land-use classifications (i.e., few cover classes on maps) on richness and rare species abundance. In a different approach to scale effects, Giralt et al. demonstrate a large-scale influence of irrigation expansion on bird community composition in non-irrigated habitats. An increase of irrigated tree orchards favored species richness up to $500 \mathrm{~m}$ away from the irrigated area. However, as specialists were replaced by generalist species, this land-transformation process had a negative effect on the dry cereal farmland bird community, which lost singular and threatened species. Such influence of surrounding habitats at large spatial scales and its implications for ecosystem function is also addressed by Perrot et al., who show that both seed and aphid predation levels in agricultural fields increased with the proportion of grassland in a $500 \mathrm{~m}$ radius buffer, regardless of the distance to the nearest grassland patch.

The effects of climate change on agro-ecosystem function, another hot topic of present day ecology, is here addressed by Díaz et al., who demonstrate that drought can have adverse effects on many ecosystem functions, in this case in dehesa silvopastoral systems. For example, seedling recruitment decreased, while abortion and predispersal seed predation increased, with higher drought intensity. Forest opening aimed at decreasing adult tree mortality under climate change scenarios will then have little or no effects on tree recruitment. Dehesas are savannahlike traditional systems created by man, but known to have high conservation value. However, the replacement of natural habitats, like true savannahs, with commercial tree plantations, like acacias, can result in loss of all biodiversity dimensions, either taxonomic, functional or phylogenetic, at regional scales. Something which was shown by Carvalho et al., who found that Amazonian bat communities were less diverse in acacia plantations than in native forests and the savannah matrix replaced by those plantations, and that this was mainly driven by greater abundance of generalist species in the latter habitat. Nevertheless, some artificial elements associated with agricultural areas can be used as complementary tools for biodiversity conservation in natural habitats. Such is the case of the water tanks studied by Lamelas-López et al., which were shown to work as biodiversity reservoirs for pristine natural ponds. Therefore, and in a broader perspective, in order to understand the true complexity of landscape fragmentation and habitat modification in agricultural systems, it is clear that we need to work with multiple dimensions, organisms and ecosystem services. The history of former land-use is very important in this context, as shown by Uribe et al. Land-use history can affect diversity of forest species in plantations replacing native forests. In particular, pine plantations that directly replaced native forests had a higher abundance of forest specialists and lower abundance of exotics and generalists than plantations on former agricultural land.

\section{Call for Action}

The current biodiversity and environmental crisis urges us to adopt more efficient and sustainable agricultural practices (Tilman, 1999) that take into account, not only increased 
productivity through environmental conservation (e.g., ecological intensification Bommarco et al., 2013), but also food security through socio-economic policies, and thus managing trade-offs between agriculture and environmental conservation (Foley et al., 2005; Brosi et al., 2008; Clough et al., 2011). The development of scientifically sound models that support sustainable landscape and land-use policies that reconcile the conservation of biodiversity and ecosystem services with agricultural productivity and guarantee the required amount and spatial distribution of habitat in the landscape, is a main challenge for research (Brosi et al., 2008; Clough et al., 2011; Martin et al., 2019; Garibaldi et al., 2021). The studies in this special issue provide not only new scientific insight into the ecological basis of such models, but also for

\section{REFERENCES}

Andersson, G. K. S., Ekroos, J., Stjernman, M., Rundlöf, M., and Smith, H. G. (2014). Effects of farming intensity, crop rotation and landscape heterogeneity on field bean pollination. Agric. Ecosyst. Environ. 184, 145-148. doi: 10.1016/j.agee.2013.12.002

Batáry, P., Holzschuh, A., Orci, K. M., Samu, F., and Tscharntke, T. (2012). Responses of plant, insect and spider biodiversity to local and landscape scale management intensity in cereal crops and grasslands. Agric. Ecosyst. Environ. 146, 130-136. doi: 10.1016/j.agee.2011.10.018

Benton, T. G., Vickery, J. A., and Wilson, J. D. (2003). Farmland biodiversity: Is habitat heterogeneity the key? Trends Ecol. Evol. 18, 182-188. doi: 10.1016/S0169-5347(03)00011-9

Bommarco, R., Kleijn, D., and Potts, S. G. (2013). Ecological intensification: Harnessing ecosystem services for food security. Trends Ecol. Evol. 28, 230-238. doi: 10.1016/j.tree.2012.10.012

Brook, B. W., Sodhi, N. S., and Bradshaw, C. J. A. (2008). Synergies among extinction drivers under global change. Trends Ecol. Evol. 23, 453-460. doi: 10.1016/j.tree.2008.03.011

Brosi, B. J., Armsworth, P. R., and Daily, G. C. (2008). Optimal design of agricultural landscapes for pollination services. Conserv. Lett. 1, 27-36. doi: 10.1111/j.1755-263X.2008.00004.X

Clough, Y., Barkmann, J., Juhrbandt, J., Kessler, M., Wanger, T. C., Anshary, A., et al. (2011). Combining high biodiversity with high yields in tropical agroforests. Proc. Nat. Acad. Sci. U.S.A. 108, 8311-8316. doi: $10.1073 /$ pnas.1016799108

Concepción, E. D., Díaz, M., Kleijn, D., Báldi, A., Batáry, P., Clough, Y., et al. (2012). Interactive effects of landscape context constrain the effectiveness of local agri-environmental management. J. Appl. Ecol. 49, 695-705. doi: 10.1111/j.1365-2664.2012.02131.x

Ekroos, J., Ödman, A. M., Andersson, G. K. S., Birkhofer, K., Herbertsson, L., Klatt, B. K., et al. (2016). Sparing land for biodiversity at multiple spatial scales. Front. Ecol. Evolut. 3:145. doi: 10.3389/fevo.2015.00145

FAO (2021). FAOSTAT Database. Available online at: http://www.fao.org/faostat (accessed August 12, 2021).

Faria, N., and Morales, M. (2021). Linking entomofauna and farmland management to enhance ecosystem services in Mediterranean drylands. Ann. Appl. Biol. doi: 10.1111/aab.12741. [Epub ahead of print].

Farwig, N., Bailey, D., Bochud, E., Herrmann, J. D., Kindler, E., Reusser, N., et al. (2009). Isolation from forest reduces pollination, seed predation and insect scavenging in Swiss farmland. Landscape Ecol. 24, 919-927. doi: 10.1007/s10980-009-9376-2

Foley, J. A., DeFries, R., Asner, G. P., Barford, C., Bonan, G., Carpenter, S. R., et al. (2005). Global consequences of land use. Science 309, 570-574. doi: 10.1126/science.1111772

Garibaldi, L. A., Aizen, M. A., Cunningham, S., and Klein, A. M. (2009). Pollinator shortage and global crop yield. Commun. Integr. Biol. 2, 37-39. doi: $10.4161 /$ cib.2.1.7425 their development and application. The speed of biodiversity decline and the strength of the environmental crisis calls for a shift in the way agricultural and other productive landscapes are treated. They must not only be seen as sources of food and other supplies for a human population in growing need and inequity, but also as functional ecological systems that allow us to obtain such supplies which, ultimately, depend on species and their interactions.

\section{AUTHOR CONTRIBUTIONS}

All authors listed have made a substantial, direct, and intellectual contribution to the work and approved it for publication.

Garibaldi, L. A., Oddi, F. J., Miguez, F. E., Bartomeus, I., Orr, M. C., Jobbágy, E. G., et al. (2021). Working landscapes need at least $20 \%$ native habitat. Conserv. Lett. 14:12773. doi: 10.1111/conl.12773

Garibaldi, L. A., Steffan-Dewenter, I., Kremen, C., Morales, J. M., Bommarco, R. Cunningham, S. A., et al. (2011). Stability of pollination services decreases with isolation from natural areas despite honey bee visits. Ecol. Lett. 14, 1062-1072. doi: 10.1111/j.1461-0248.2011.01669.x

Hipólito, J., Boscolo, D., and Viana, B. F. (2018). Landscape and crop management strategies to conserve pollination services and increase yields in tropical coffee farms. Agric. Ecosyst. Environ. 256, 218-225. doi: 10.1016/j.agee.2017.09.038

Holzschuh, A., Steffan-Dewenter, I., and Tscharntke, T. (2008). Agricultural landscapes with organic crops support higher pollinator diversity. Oikos 117, 354-361. doi: 10.1111/j.2007.0030-1299.16303.x

Jönsson, A. M., Ekroos, J., Dänhardt, J., Andersson, G. K. S., Olsson, O., and Smith, H. G. (2015). Sown flower strips in southern Sweden increase abundances of wild bees and hoverflies in the wider landscape. Biol. Conserv. 184, 51-58. doi: 10.1016/j.biocon.2014.12.027

Kennedy, C. M., Lonsdorf, E., Neel, M. C., Williams, N. M., Ricketts, T. H., Winfree, R., et al. (2013). A global quantitative synthesis of local and landscape effects on wild bee pollinators in agroecosystems. Ecol. Lett. 16, 584-599. doi: 10.1111/ele.1 2082

Martin, E. A., Dainese, M., Clough, Y., Báldi, A., Bommarco, R., Gagic, V., et al. (2019). The interplay of landscape composition and configuration: new pathways to manage functional biodiversity and agroecosystem services across Europe. Ecol. Lett. 22, 1083-1094. doi: 10.1111/ele.1 3265

Ricketts, T. H., Regetz, J., Steffan-Dewenter, I., Cunningham, S. A., Kremen, C., Bogdanski, A., et al. (2008). Landscape effects on crop pollination services: are there general patterns? Ecol. Lett. 11, 499-515. doi: 10.1111/j.1461-0248.2008.01 157.x

Rundlöf, M., Andersson, G. K. S., Bommarco, R., Fries, I., Hederström, V., Herbertsson, L., et al. (2015). Seed coating with a neonicotinoid insecticide negatively affects wild bees. Nature 521, 77-80. doi: 10.1038/nature1 4420

Tarjuelo, R., Concepción, E. D., Guerrero, I., Carricondo, A., Cortés, Y., and Díaz, M. (2021). Agri-environment scheme prescriptions and landscape features affect taxonomic and functional diversity of farmland birds. Agric. Ecosyst. Environ. 315:107444. doi: 10.1016/j.agee.2021.107444

Tilman, D. (1999). The ecological consequences of changes in biodiversity : Perspectives. Ecology 80, 1455-1474. doi: 10.1890/0012-9658(1999)0801455:TECOCI2.0.CO;2

Tilman, D. (2001). Forecasting agriculturally driven global environmental change. Science 292, 281-284. doi: 10.1126/science.105 7544

Tomlinson, I. (2013). Doubling food production to feed the 9 billion: A critical perspective on a key discourse of food security in 
the UK. J. Rural Stud. 29, 81-90. doi: 10.1016/j.jrurstud.2011.0 9.001

Vergara, C. H., and Badano, E. I. (2009). Pollinator diversity increases fruit production in Mexican coffee plantations: The importance of rustic management systems. Agric. Ecosyst. Environ. 129, 117-123. doi: 10.1016/j.agee.2008.08.001

Viana, B. F., Boscolo, D., Neto, E. M., Lopes, L. E., Lopes, A. V., Ferreira, P. A., et al. (2012). How well do we understand landscape effects on pollinators and pollination services? J. Pollinat. Ecol. 7, 31-41. doi: 10.26786/1920-7603(2012)2

Conflict of Interest: The authors declare that the research was conducted in the absence of any commercial or financial relationships that could be construed as a potential conflict of interest.
Publisher's Note: All claims expressed in this article are solely those of the authors and do not necessarily represent those of their affiliated organizations, or those of the publisher, the editors and the reviewers. Any product that may be evaluated in this article, or claim that may be made by its manufacturer, is not guaranteed or endorsed by the publisher.

Copyright $(2021$ Andersson, Concepción, Hipólito, Morales and Persson. This is an open-access article distributed under the terms of the Creative Commons Attribution License (CC BY). The use, distribution or reproduction in other forums is permitted, provided the original author(s) and the copyright owner(s) are credited and that the original publication in this journal is cited, in accordance with accepted academic practice. No use, distribution or reproduction is permitted which does not comply with these terms. 